\title{
The War Emergency Board of American Plant Pathologists
}

\author{
C. Lee Campbell, Professor, Paul D. Peterson, Historian and Lecturer, and Clay S. Griffith, Research Assistant, \\ Department of Plant Pathology, North Carolina State University, Raleigh 27695-7616
}

By the second decade of the twentieth century, plant pathology in the United States was developing rapidly into a mature, professional science. The level of that development can be viewed clearly through the activities of a committee appointed in 1918 as a response to the national emergency caused by World War I and known as the War Emergency Board of American Plant Pathologists. The formation of the War Board is a significant event in the history of plant pathology in the United States, not so much for what the Board contributed to the war effort, but rather because it became an extraordinary exercise in professional self-examination. The study of the organization of American phytopathological resources necessitated by the war, as well as the Board's examination of the current level of the understanding of plant diseases and the ability to forge solutions to those problems, serve as an excellent lens through which to view the science of plant pathology in its formative years. As a lasting legacy, the War Board crystallized an understanding of the need for a level of cooperation and communication that the science had not recognized previously, and established a precedent for the continuation of such interactions after the wartime emergency passed.

By the time the ninth annual meeting of the American Phytopathology Society (APS) was held in Pittsburgh, Pennsylvania from 28 December 1917 to 1 January 1918, the United States had been fighting in World War I for nearly 8 months. Food production and distribution, both within the United States and for our troops and allies in Europe, were the focus of national attention due to the amounts of food consumed by the non-producing allied armies, the quantities lost as cargoes sunk at sea, and the poor wheat crop of 1916 , the year of the disastrous epidemic of stem rust. Although United States wheat production had increased greatly in 1917, the threat of losses and wastage in food crops and vital war provisions due to plant diseases in the

Corresponding author: C. L. Campbell
E-mail: lee_campbell@ @csu.edu

Accepted for publication 15 September 1997.

Publication no. D-1997-1121-01S

(C) 1998 The American Phytopathological Society field, in transit to market, and in grocery stores were realistic, national concerns.

George R. Lyman, director of the recently formed United States Department of Agriculture (USDA) Plant Disease Survey, in his paper relating to war problems in botany presented to a joint session of the APS, Section G of the American Association for the Advancement of Science (AAAS), and the Botanical Society of America, summarized the feelings of many of the plant pathologists attending the Pittsburgh meeting. Lyman noted that the current period of national danger was one that offered botanists an "unrivaled opportunity to win the full recognition our science now lacks...by showing what botanical research and the application of botanical knowledge can do in solving the problems of increased food production" (5). C. L. Shear, in the conclusion of his paper for the symposium "Phytopathology in Relation to War Service," echoed the importance of the role to be played by phytopathologists and demonstrated the patriotic fervor that infused the meeting. " "Food will win the war' is the slogan of the Food Administration. Is not the pa- thologist, in preventing these enormous losses of food, performing as effective service for his country as the man in the trenches?" (10)

The concrete fulfillment of the desire to contribute to the war effort came with the establishment of the War Emergency Board of American Plant Pathologists. Organized along regional lines, the War Emergency Board was "charged with the responsibility of stimulating and accelerating phytopathological work to the end that, in this present world crisis, the reduction of crop losses from diseases would be made most effective as a factor in the increase of our food supply" (18). Its goal was the encouragement of cooperation with and among existing organizations at all levels of government and in private industry and among all the workers of the phytopathological profession. The Board's authority would come only from the scientific standing of its membership, because it had no governmental authority and initially no financial backing or operating budget.

The individuals named to the Board (Fig. 1) were enthusiastic, prominent sci-

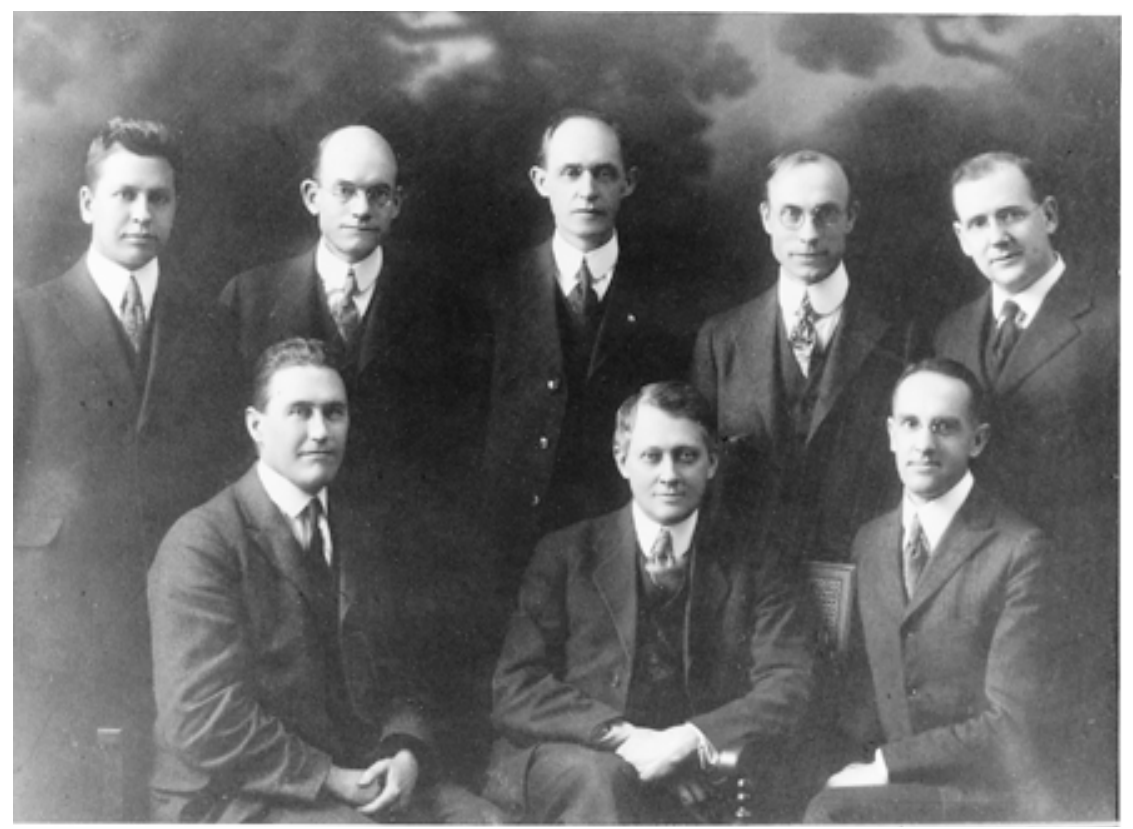

Fig. 1. The Eight Commissioners of the War Emergency Board of American Plant Pathologists. First row (sitting, left to right): W. R. McCubbin, H. H. Whetzel, H. P. Barss; second row (standing, left to right): E. C. Stakman, G. R. Lyman, H. W. Barre, F. D. Kern, G. H. Coons. Courtesy of the Department of Plant Pathology, University of Minnesota, St. Paul. 
entists and leaders. Herbert H. Whetzel, APS president in 1915 and chair of the Department of Plant Pathology at Cornell University, was named chairman and commissioner for the North East. Howard P. Barss, head of the Department of Botany and Plant Pathology at Oregon Agricultural College, Corvallis, was named commissioner for the West. E. C. Stakman, head of the Section of Plant Pathology at the University of Minnesota, served as commissioner for the Great Plains. George $\mathrm{H}$. Coons, of the Department of Botany and Plant Pathology at Michigan Agricultural College, served as commissioner for the North Central States East. Frank D. Kern, head of the Department of Botany at the Pennsylvania State College, was named commissioner for the Central East. H. E. Barre, director of the South Carolina Agricultural Experiment Station, served as commissioner for the South. George R. Lyman was named commissioner at large to represent the USDA. W. A. McCubbin, of the Dominion Laboratory of Plant Pathology in St. Catharines, Ontario, was added as commissioner for Canada. Five of the members of the Board had been or would go on to be president of APS (Whetzel, 1915; Stakman, 1922; Lyman, 1923; Barss, 1928; Coons, 1936) and one (Kern) had served as vice-president.

Shortly after the Pittsburgh conference, Chairman Whetzel issued "A Call to the Colors," a document that was circulated as quickly as possible to every available phytopathologist. He wrote, "Every American science is mobilizing for the grand assault on the enemy. One of the youngest of American Sciences, Plant Pathology, is preparing to do its full share.... No agricultural scientist is now more important in the vital problem of maintaining maximum crop production than the plant pathologist, be he in research, teaching, or extension work.... During the past year we have done all that was expected of us, we must now do more" (20).

This document was the blueprint of the work that was to follow for the War Emergency Board, detailing the "emergency projects already defined." Commissioner
Kern had responsibility, along with V. B. Stewart of Cornell University and C. R. Orton of the Pennsylvania State College, for conducting a manpower census to determine the availability and expertise of plant pathologists and botanists who could work on plant diseases, so that the Board would "be in a position to intelligently and effectively work for the conservation and distribution of trained plant pathologists in the busy days before us." Commissioner Coons was charged with gathering all available data on the availability of a dependable "supply of fungicides, disinfectants, and machinery for their application at a fair price to the farmer...." Commissioner Stakman was to assemble reports on the availability, experience, and special qualification of workers to undertake or redirect their work to include "problems in seed disinfection; in promising new field fungicides; in disease resistant strains and varieties; and in many other directions [that] call imperatively for solution." Commissioner Lyman was to continue his work to expand the recently organized USDA Plant Disease Survey in order to provide "prompt, accurate, and complete knowledge of the appearance and spread of pathogenes [sic] destructive to our staple crop[s]..." which would allow "field pathologists to warn their growers in time to prevent vast losses...in these days when waste of every kind is criminal." He was also to collect and provide accurate estimates of losses due to plant diseases, because "demands for financial support in the reduction of these losses must depend largely on our ability to show what such losses actually are." Commissioner Whetzel served as the contact for information on extension work, to ensure that all those "having to do with the appropriation of funds for food conservation should have the vital importance of crop disease control fully and effectively placed before them," and to fulfill the role of the Board as a distributing agent for new and successful extension methods and for information on plant disease control among the states. He was also responsible for coordinating information on innovations and opportunities

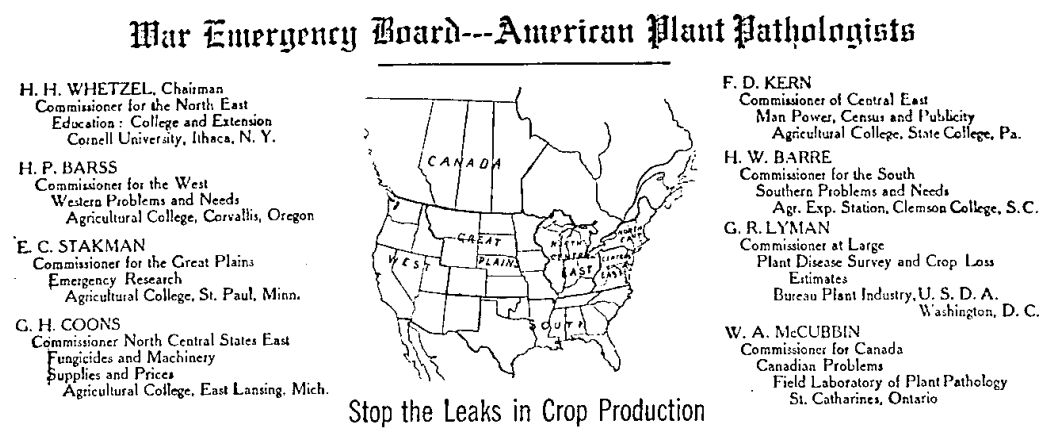

Fig. 2. Letterhead of the War Emergency Board of American Plant Pathologists that was also used as the basis for the cover of Board's Mid-Year and Final Reports. Courtesy of Special Collections, Iowa State University, Ames.

in education of students to fill the "inadequate and depleted ranks" of plant pathologists. All of these duties, and the others that the Board undertook, implied the most important aspect of the Board's work: that is, creating a network of communication and coordination among plant pathologists who were used to the relative professional confinement of their institution, their scientific subdiscipline, or their geographical region; a confinement that was relieved to some degree by the existence of informal communication networks and the more formal ones of a professional society and journal. These previous contacts, however, did not represent the pitched level of communication and informational exchange that the War Board would inspire.

First and foremost, the War Emergency Board had to answer the question of who would do the vital work in plant pathology. The number of plant pathologists, already relatively small and inadequate in the minds of many at the onset of the War, was being depleted rapidly by military and industrial demands. In the Board's Midyear Report (Fig. 2), Kern reported that of those replying to the manpower survey, "including members of the Phytopathological Society, not more than 280 can be regarded as trained plant pathologists" (18). Also, of those responding, 62 were in Class 1-A in the draft, and the listing of those who had already entered into military service was "rather imperfect," but there was enough information at hand to "indicate that the list is already comparatively large and...is constantly increasing." The Board offered several suggestions to overcome the shortage of trained plant pathologists. First, research on less important crops could be dropped or reduced to a minimum effort so that more time could be devoted to emergency research and extension. Second, instructors and professors could be relieved of a portion of their teaching in order to make more time for emergency work. And third, "women might be used in the laboratory for routine work, allowing the pathologist more time for extension work" (8). And finally, in "A Call to the Colors," Whetzel had identified the need for scientists from other lines, such as general botany, to be brought into the work on plant diseases, and he called for additional emergency courses at the various colleges to train recruits (20). This activity led to the development of plans for the rapid expansion of graduate programs in plant pathology, especially at those universities with established programs such as Cornell, Minnesota, and Wisconsin.

Along with the need for information on available manpower resources, it was essential to gain a broader grasp of the range and scope of the most dangerous crop diseases. Towards this end, and with the goal of prioritizing the most significant problems, Commissioner Lyman called for the 
use of the Plant Disease Survey to "collect information on plant diseases in the United States covering such topics as prevalence, geographical distribution, severity, etc., and...to make this information immediately available to all persons interested, especially to those concerned with disease control" (17). Lyman, director of the Survey, felt that such knowledge, "important in times of peace...is imperative now in times of war, when, with our numbers reduced by military service, we must make sure that we are wasting no time on problems of lesser importance" (6). He demonstrated the clear war applications of the Survey's estimates of losses due to diseases when he stated that, in the year 1917, "if bunt and loose smut of wheat had been completely controlled we could have furnished the Allies an additional 33 million bushels." Additionally, "the loss from oat smut amounted to almost as much as our export [of] ninety-three and one-half million bushels of this cereal to the Allies and neutral nations during the past year" (18). The Plant Disease Survey marked another milestone in the continuing development of cooperation between federal and state pathologists. Its organization, support, and growth indicated the widespread recognition of the need for increased communication among plant disease workers.

It was this increased level of cooperation and communication that the War Emergency Board strove to create and maintain among plant pathologists. Such cooperation, they believed, would have "farreaching possibilities affecting American plant pathology" (4). The members of the War Board, each a prominent scientist in his own right, brought together plant pathologists from different states within each region to see how they might attack common problems of an immediate nature, and to see how they might work together to ensure the greatest amount of food production in the time of national need. Their goal was to "coordinate research work and to secure voluntary cooperation in the solution of pressing problems by working through the established state and federal agencies." Board members also sought to help their colleagues in each region identify and perhaps postpone less essential projects, so that other problems of a "distinctly emergency nature" could be pushed to the forefront of research agendas.

Those assembled at the various regional conferences convened by the War Board throughout 1918 took up projects on diseases of specific crops and on individual diseases of special importance. At these regional meetings, leaders were selected to collect and disseminate information on diseases of specific crops, and those scientists interested in a particular commodity were designated as a committee to act in cooperation with the leader. The primary activity of the crop committees was the exchange of information on new and existing methods of disease control, as well as the planning of studies that might be undertaken jointly across the region to evaluate new control methods. When projects were of major importance in more than one district, they were elevated to the status of general projects and a general leader was designated by the Board (18).

Intense attention to specific diseases or commodities had far-reaching consequences for the science beyond the quest for wartime production. When possible, and when needed, the Board encouraged the convening of project conferences, a logical outgrowth of the district conferences and the organization of the cooperative projects (19). An example of one of the most successful general projects was that on seed treatment for cereals. Adopted in all of the districts, the project arose when pathologists in district conferences began to review the methods in use for seed treatment and found that there were large gaps in the available information in this area and that the methods generally recommended for seed treatment of cereals "varied greatly in different parts of the country." Within the year, there was nearly total agreement that the so-called dry formaldehyde treatment could be recommended as safe, simple, and quite effective for use wherever oats were grown for a cost of about three cents per acre (21). What could have taken many years to accomplish "under the old system" of relatively isolated and independent pathologists had been effected in 1 year.

The efforts of the members of the War Emergency Board in the areas of communication and cooperation helped speed the transformation of American pathologists from a community in relative isolation to a community of interacting scientists who shared a common goal and vision-to increase the production of food crops through the practical application of knowledge on the control of plant diseases. The free and open exchange of views and data allowed pathologists to push "forward the solution of many problems far beyond what could have been expected under the former conditions of suspicion and personal isolation in which [they] worked" (19). The result was an emphasis on studies to solve the most pressing and important plant disease problems with the rapid dissemination of practical information, not through the printed pages of professional journals but through conferences, mimeographed reports, information sheets, and personal correspondence.

The War Emergency Board also brought rapid and intense coordination to bear on another important aspect of plant pathology - the role of fungicides and spraying equipment in disease control. General restrictions on industrial production brought on by the War placed the manufacture of fungicides and spray machinery under the same embargoes and limitations as many other items that were not directly related to the military. Additionally, the limited availability of fungicides was exacerbated by high prices, posing still greater problems for growers. Fungicides had become a common and essential ingredient in the successful management of plant diseases on many vital food crops in the two decades before the War. For example, Bordeaux mixture was essential for spraying potatoes; commercial lime-sulfur and finely ground sulfur were needed to reduce damage on apples due to diseases; corrosive sublimate (mercuric chloride) and formaldehyde were well-established as treatments for seed potatoes; and the dry formaldehyde method was a valuable means of treating cereal seeds to prevent certain types of smut diseases (7).

Shortly after his appointment to the War Emergency Board, however, Commissioner Coons found that many dealers, because of the uncertainty of price and demand, were not carrying supplies of the various fungicides adequate to meet anticipated demand. This potential shortage of fungicides, coupled with the placement of an embargo on "all railroad shipments of spray machinery and materials" early in the year, could have given rise to a potentially disastrous situation with regard to crop protection against diseases for the 1918 growing season if definitive steps had not been taken to resolve the situation (18). The essential nature of spray machinery for the production of food was brought to the attention of the Director General of Railroads by Coons and Whetzel, and the embargo was subsequently lifted. They also helped convince the War Industries Board to allow "a release of materials for use in crop conservation" to meet the need for increased manufacturing of fungicidal compounds. Then, later in the year, meetings were held with spray machinery manufacturers, who were under pressure from the government proclamations for "curtailment in all lines of production aside from the absolutely essential ones" (19). The manufacturers agreed at the conference to "abandon certain lines and styles which were no longer considered necessary to meet the varied demands of the trade, thus making the first step in standardization of what is a very much individualized branch of machinery production."

Thus, the War Emergency Board helped assure the availability of compounds essential for disease control and, through the necessity of insuring an adequate supply, encouraged standardization of spray machinery. This effort demonstrated how significant the use of chemical fungicides had already become in the first quarter of the twentieth century. The Board's work in this area also had the unforeseen result of initiating a more open and frequent dialogue between plant pathologists and the representatives of the leading commercial 
concerns involved in the production and sale of spraying equipment and of fungicides themselves. Whereas, prior to the War, the feeling on the part of many of the rank and file of plant pathology was that "cooperation with commercial concerns necessarily meant entangling relationships and perhaps disingenuous using of the pathologist's statements in advertising and the like" (19), through the personal efforts and educational programs of the War Board, a greater effort would be made "to keep in touch with men of this trade."

The War Emergency Board's single most famous contribution to a disease control program did not involve the routine use of fungicidal sprays. Rather, it concerned their coordination and promotion of efforts to reduce the destruction of stem rust of wheat through the eradication of the common barberry. The barberry eradication program, under the leadership of the Bureau of Plant Industry, predated the War Emergency Board and was implemented as a direct result of the staggering losses of wheat due to stem rust in 1916, estimated at up to 300 million bushels in North America. Additionally, the battle against stem rust was spurred on by the vital need for a grain surplus to supply the Allies in their prosecution of the War in Europe.

The eradication campaign in the United States had begun through the efforts of several influential individuals $(H$. L. Bolley of North Dakota State University, E. C. Stakman of the University of Minnesota, and M. A. Carleton of the USDA), who realized the magnitude of the barberry problem and had a vision of how to solve it. They formulated the initial strategy for barberry eradication in early 1917 , but the USDA leadership felt that a law imposing the eradication plan on a national level was impractical, if not unconstitutional. The United States' entry into the War, however, increased the desire of these men and other concerned phytopathologists, as well as the federal government, to insure a healthy wheat crop. The plant pathologists concerned with eradication began to do everything possible to influence individual states to undertake barberry eradication. As agent in charge for the USDA, Stakman worked tirelessly on the eradication campaign for 15 months, beginning in February 1918. His efforts were facilitated in part through his membership on the War Emergency Board and his ability to meet with and encourage other pathologists to action throughout the country. The War Emergency Board, in a February meeting in Washington, DC, passed a resolution to "endorse and support the efforts to eradicate the common barberry" in the wheat belt of the upper Mississippi Valley with the hope that "all pathologists will assist in carrying...out and in translating...into action" $(5,6)$ the program. The program had to be a truly cooperative federal-state undertaking at a time when "the relations between some of the states and the federal Department of Agriculture were not too good" (14). Because the federal government was "making the removal of the barberry purely voluntary," the campaign also had to be one in which any legal requirements to make the eradication of barberries compulsory had to come from the states, not the federal government (12).

As the barberry eradication campaign got under way, appeals for the destruction of barberry bushes were made in the name of patriotism. In a press release from the South Dakota State College of Agriculture, the barberry bush was described as "decidedly pro-German," and both urban and rural Americans were told that it was "disloyal to allow the common barberry bush to live-it must be treated as a dangerous enemy alien" (3). E. M. Freeman declared, "The common barberry is an 'aid and comfort to the enemy" "and that if you have dug out the common barberry, "you have made the wheat crop of Minnesota more nearly safe against the dreaded rust disease" (2). The federal government also threw its considerable weight behind the campaign. Secretary of Agriculture Houston, for example, "requested the authorities of Michigan to join in the eradication campaign which seeks to rid the great grain growing states of this destructive pest. The matter is a war measure of utmost importance" (16). In 1918, a total of 1,842,000 bushes were found, of which 1,690,000 were dug out and destroyed (1). Many additional bushes in and around towns and cities were removed by organizations such as the Boy Scouts, high school students, and members of various other civic groups.

When the campaign began in April 1918, North Dakota was the only state that already had a barberry eradication law in force, thanks to the influence of $\mathrm{H}$. L. Bolley. During 1918, officials, scientists, and agriculturists in Colorado, Nebraska, South Dakota, Minnesota, Iowa and Michigan debated legal measures to secure the complete eradication of the common barberry (13). Within the next several years, legal authority for barberry eradication was either passed in new legislation or found through reinterpretation of existing legislation in all the states in the targeted eradication area. Educational and outreach efforts were so successful, bringing widespread cooperation among farmers and town dwellers alike, that actual enforcement of the laws was needed only infrequently. Even after 1918, when the wardriven fervor ended, the eradication program thrived and marched on with a farm-to-farm survey in each of the 13 target states, a very large public works project by the scale of the times.

Unlike barberry eradication, the immediacy of many of the activities of the Emergency War Board of American Plant Pathologists became moot when World War I ended on 11 November 1918. Pres- entations at the 10th annual meeting of the APS highlighted the successes of the Board. The most immediate recognizable gain was a new wealth of shared information that had been made available to plant pathologists in every state in the nation and then to thousands of actual food and fiber producers through the existing cooperative extension system of county agents. Another short-term gain came from the temporary enlistment of a large number of botanists from other areas of expertise into plant pathology. Although this recruitment did not provide an actual numerical increase (compared to pre-War numbers) in those engaged in plant pathology, it did bring a number of workers with very different training and techniques into the profession, from which could come "striking and valuable contributions" to plant pathology (15). And, perhaps more than any other single factor, the Board served as a catalyst for the emergence of a national identity and perception of selfworth for the practitioners of the relatively new science of phytopathology. W. W. Robbins, a botanist at the Colorado Agricultural College and Experiment Station, wrote to Chairman Whetzel even before the War's end that "in years to come when we look back upon the development of the science, the Board will have much to its credit in placing plant pathology on a firm basis, in establishing a program and viewpoint of work, and in creating an esprit de corps among pathologists, which does not have its equal in any other field" (9).

Further, the recognition by the public and policy makers that plant diseases caused significant "leaks in crop production" was heightened due to the vital need for food in a world at war. The realization that the "plant doctors" had within their arsenal effective weapons against many important plant diseases was also made much more evident during the time of national crisis. Financial support from the federal government and the states for programs such as the Plant Disease Survey and the barberry eradication campaign increased. Agriculturists benefited from the rapid and open dissemination of the results of studies on controlling plant diseases.

The recognition of the urgent need for continued cooperation was a "dominant note in the papers and discussion of the biologists at the Baltimore meeting (23-28 December 1918) of the American Association for the Advancement of Science and the affiliated societies" (11). The valuable work of the Board was too important to be allowed to relapse to pre-War status. The War Emergency Board concluded its operations in early 1919, but it was replaced on a permanent basis by the Advisory Board of American Plant Pathologists, which would continue to function on behalf of the American Phytopathological Society to help improve communication and cooperation among plant pathologists 
and their colleagues in allied fields, domestically and internationally.

The lasting successes achieved by the War Emergency Board must be attributed to a combination of interlinking factors. The commissioners were enthusiastic, dedicated individuals who knew their science and were excited about the contributions plant pathologists could make to the welfare of the nation and the world. From the standpoint of the maturity of the science with proven successes in teaching, research, and extension activities, the technology available to solve practical problems based upon an ever-growing understanding of biological processes, and the identified, critical need to reduce wastage in food production and forest products due to plant diseases, the time was right for plant pathologists to demonstrate their worth and the real value of their science. Patriotism, national needs, a level of accumulated knowledge equal to the task, an unparalleled spirit of cooperation, and the enthusiastic leadership of dedicated, scientific visionaries converged near the end of the second decade of the twentieth century to signal the transition of plant pathology from a science in its formative years to one ready to assume its rightful place as one of the mature, natural sciences in the United States.

\section{ACKNOWLEDGMENTS}

We thank Steven R. Shafer and D. Michael Benson for their comments on an earlier draft on this manuscript.

\section{LITERATURE CITED}

1. Anonymous. 1922. Proceeding: Second Annual Conference for the Prevention of
Grain Rust, November 14, 1922, University Farm, St. Paul. Topical Files, Barberry Eradication I. U. S. Dep. Agric. Systematic Botany and Mycological Laboratory, Beltsville, MD.

2. Freeman, E. M. 1918. The common barberry and enemy of wheat. The University of Minnesota, College of Agriculture, Extension Division. Special Bulletin No. 26.

3. Larsen, C. Press Release \#901, April 22, 1918. Cooperative Agricultural Extension Work, South Dakota State College of Agriculture and Mechanic Arts and U. S. Dep. Agric. Cooperating. Brookings, S. D. Topical Files, Barberry Eradication I. U. S. Dep. Agric. Systematic Botany and Mycological Laboratory, Beltsville, MD

4. Lyman, G. R. 1918. Minutes of the War Emergency Board of American Plant Pathologists. Science 47:210-213.

5. Lyman, G. R. 1918. The need for organization of American botanists for more effective prosecution of war work. Science 47:279-285.

6. Lyman, G. R. 1918. The relation of phytopathologists to plant disease survey work. Phytopathology 8:219-228.

7. Osmun, A. V. 1918. Minutes of the War Emergency Conference of plant pathologists of the Northeast, meeting held March 1-2, Boston, MA. Herbert Hice Whetzel Papers, Department of Manuscript and University Archives, Cornell University Libraries, Ithaca New York.

8. Peltier, G. L. 1918. Appendix: Atlanta Conference, Minutes of the War Emergency Conference of Southern Pathologists. Phytopathology 8:190-193.

9. Robbins, W. W. to H. H. Whetzel, October 26, 1918. Herbert Hice Whetzel Papers, Department of Manuscript and University Archives, Cornell University Libraries, Ithaca New York.

10. Shear, C. L. 1918. Pathological aspects of the federal fruit and vegetable inspection service. Phytopathology 8:155-160.

11. Shear. C. L. 1919. Cooperation and individu- alism in scientific investigation. Sci. Mon. 9:342-348

12. Stakman, E. C., quoted from War Emergency Board-American Plant Pathologists. 1918. Notes on the Conference meeting of the War Emergency Board, American Plant Pathologists, held at LaFayette, Indiana March 15th. Herbert Hice Whetzel Papers, Department of Manuscript and University Archives, Cornell University Libraries, Ithaca New York.

13. Stakman, E. C. 1919. The black stem rust and the barberry. Pages 75-100 in: Yearb. U. S. Dep. Agric. GPO, Washington, DC.

14. Stakman, E. C., quoted from Christensen, C. M. 1984. E. C. Stakman, Statesman of Science. The American Phytopathological Society, St. Paul, MN.

15. Stevens, N. L. 1918. American botany and the Great War. Science 48:177-179.

16. Taft, L. R. and G. H. Coons. 1918. Michigan Nursery and Orchard Inspections: Kill the Barberry. U. S. Dep. Agric. Bureau of Plant Industry; and Michigan State Inspector of Orchards and Nurseries, Office of Cereal $\mathrm{Pa}-$ thology. Bulletin No. 5.

17. U.S. Dep. Agric. Bureau of Plant Industry. Plant Disease Survey. 1917. Introductory statement. The Plant Disease Bulletin 1:1.

18. War Emergency Board-American Plant Pathologists. 1918. Midyear Report, June 25, 1918. American Phytopathological Society Records, Special Collections, Iowa State University, Ames.

19. War Emergency Board-American Plant Pathologists 1918. Final Report for the year ending December 31, 1918. American Phytopathological Society Records, Special Collections, Iowa State University, Ames.

20. Whetzel, H. H. January 8, 1918. A Call to the Colors. American Phytopathological Society Records, Special Collections, Iowa State University, Ames.

21. Whetzel, H. H. 1919. Cooperation among plant pathologists. The Cornell Countryman $16: 13,36,38,40$. 